\title{
HUBUNGAN ADIKSI GAME ONLINE DENGAN KUALITAS TIDUR PADA ANAK DI SMP TERATAI PUTIH GLOBAL BEKASI TAHUN 2020
}

\author{
Khadijah Ratna Widiyani ${ }^{1}$, Fereza Amelia ${ }^{2}$, Aulia Chairani ${ }^{3}$ \\ ${ }^{1}$ Program Studi Sarjana Kedokteran, Universitas Pembangunan Nasional "Veteran” Jakarta \\ Email: adiswibisono@gmail.com \\ ${ }^{2}$ Departemen Anak Kedokteran, Universitas Pembangunan Nasional "Veteran" Jakarta \\ Email: doc_fea@yahoo.com \\ ${ }^{3}$ Departemen Kesehatan Masyarakat Kedokteran, Universitas Pembangunan Nasional "Veteran" Jakarta \\ Email:dr.aulia.chairani@gmail.com
}

Masuk : 27-06-2020, revisi: 29-03-2021, diterima untuk diterbitkan : 10-04-2021

\begin{abstract}
ABSTRAK
Perkembangan teknologi yang kurang bijak menimbulkan beberapa masalah, salah satu contoh masalah yang muncul adalah adiksi game online yang telah menjadi hiburan global termasuk di Indonesia. Terdapat 4,388 juta pengguna internet di seluruh dunia dengan penetrasi sebesar 57\%, dan sebanyak 30\% dari jumlah tersebut bermain game secara online, dengan prevalensi adiksi internet pada remaja lebih tinggi di Asia dibandingkan Amerika atau Eropa. Salah satu bentuk gejala dari adiksi game adalah menghabiskan waktu untuk bermain game online yang membuat penderita kekurangan jam tidur sehingga dapat membuat kualitas tidur penderita adiksi menjadi buruk dan menggganggu fungsi kehidupan sehari-hari. Penelitian ini dilakukan untuk menilai hubungan antara adiksi game online tersebut dengan kualitas tidur pada anak di SMP Teratai Putih Global Bekasi. Penelitian ini bersifat analitik observasional dengan desain cross-sectional menggunakan kuesioner Indonesian Online Game Addiction dan Pittsburgh Sleep Quality Index yang telah tervalidasi. Pengambilan sampel sebanyak 51 responden dilakukan secara stratified random sampling. Hasil analisis bivariat penelitian mengatakan adanya hubungan yang signifikan antara adiksi game online dengan kualitas tidur ( $\mathrm{p}=0,001, \mathrm{CI}=95 \%$ ) pada anak di SMP Teratai Putih Global Bekasi Tahun 2020. Penelitian tentang hubungan adiksi game online dan kualitas tidur masih sangatlah sedikit, belum terdapat penjelasan ilmiah yang lengkap terkait fenomena ini, sehingga dibutuhkan penelitian lebih lanjut.
\end{abstract}

Kata Kunci: adiksi game online, anak, kualitas tidur, SMP

\begin{abstract}
Technology advancement that wasn't dealt with wisely could lead to some problems, one of the exampel is online game addiction, a global sensation that spread through even to Indonesia. There are 4,388 millions of internet user all over the world, with a penetration of $57 \%$, and $30 \%$ of them use the internet to play games online, with the prevalention of internet addiction in teenagers higher in Asian countries rather than in America or Europe. One of the symptoms of online game addiction is spanding and wasting too much time in playing online games resulting in lack of sleep and poor sleep quality that could hinder daily function. This study was done to determine the association between online game addiction and sleep quality of children at SMP Teratai Putih Global Bekasi. This is an observational analytic study with cross-sectional design using validated Indonesian Online Game Addiction Questionnaire and Pittsburgh Sleep Quality Index. There are a total of 51 samples in the study, the sampling was done with stratified random sampling. The result of the bivariate analysis in this study is that there is a significant association between online game addiction and sleep quality $(p=0,001, C I=95 \%)$ of children at SMP Teratai Putih Global Bekasi 2020. Only a few research have been conducted on the association between online game addiction and sleep quality, there's not enough scientific explanation on the phenomenon, so further research is needed.
\end{abstract}

Keywords: online game addiction, children, sleep quality, SMP 


\section{PENDAHULUAN}

\section{Latar Belakang}

Adiksi adalah suatu kondisi kompleks pada otak yang bermanifestasi dengan penggunaan suatu substansi secara konstan walaupun dengan efek samping yang merusak (APA, 2013). Adiksi komputer atau game adalah penggunaan komputer dan game secara kompulsif atau berlebihan yang mengganggu kehidupan sehari-hari seperti mengisolasi diri mereka sendiri dari kontak sosial, dan fokus hampir secara keseluruhan terhadap pencapaian game daripada urusan pada dunia nyata (Chiu et. al., 2004; Griffiths, 2010; Weinstein, 2010). Penjelasan adiksi terhadap game sudah tercantum dalam Diagnostic and Stastistic Manual of Mental Disorders (DSM-5) milik American Psychiatric Association (APA). Adiksi game juga sudah dimasukkan ke dalam International Classification of Diseases 11th Revision dari WHO dengan nama Gaming Disorder yang dikarakterisasi dengan pola bermain game yang persisten atau berulang, baik berupa online yaitu menggunakan internet atau secara offline (APA, 2013; WHO, 2019). Subtipe dari adiksi internet dan video game yang paling banyak divalidasi pada penelitian-penelitian adalah adiksi video game, terutama game yang dimainkan secara online (Sussman et. al., 2018).

Terdapat 4,388 juta pengguna internet di seluruh dunia dengan penetrasi sebesar $57 \%$, dan sebanyak 30\% dari pengguna internet tersebut menggunakannya untuk bermain game secara online (We Are Social, 2019). Adiksi internet telah menjadi masalah yang berkembang di negara Asia. Terdapat peningkatan sebesar tiga kali lipat dari jumlah pria berusia 20 tahun yang menderita adiksi internet di Jepang dari tahun 2013 ke tahun 2018 (WHO, 2019). Prevalensi adiksi internet pada remaja ditemukan lebih tinggi di Asia dibandingkan Amerika atau Eropa. Meningkatnya akses internet memudahkan akses bagi pengguna untuk bermain game secara online. Game online ini telah menjadi salah satu bentuk hiburan berskala global. Fenomena yang sama juga terjadi di Indonesia, seringnya bermain game online menduduki urutan keenam dalam kategori penggunaan internet (APJII, 2018).

Perlu diperhatikan bahwa game mempengaruhi kualitas tidur, karena bermain game biasanya merupakan aktivitas pada malam hari. Bermain game pada malam hari mengorbankan waktu tidur. Waktu tidur yang kurang, siklus tidur-bangun yang terhambat, dan gangguan tidur umum terjadi pada anak muda dan remaja, dan penyebabnya bervariasi (Hale et. al., 2015). Dilaporkan juga dari penelitian sebelumnya oleh Sosso et. al. (2018) bahwa paparan dari cahaya, seperti dari perangkat elektronik, dapat mengganggu ritme sirkardian, siklus melatonin, dan plastisitas serebral. Cahaya warna biru (blue light) yang biasa terdapat pada alat elektronik yang kita gunakan seperti smartphone dan TV, menyebabkan behavioural arousal, peningkatan kortikosteron dan memperlambat onset tidur (Sosso et. al., 2018; Pilorz et. al., 2016). Selain itu, penelitian lain menunjukkan bahwa total tidur REM setelah bermain game di komputer lebih singkat dibandingkan kelompok kontrol (Higuchi et. al., 2005).

Berdasarkan penelitian sebelumnya adiksi game online dapat berpengaruh terhadap kualitas tidur, tapi hanya sedikit yang meneliti hubungan adiksi game online dengan kualitas tidur. Oleh karena itu peneliti tertarik untuk meneliti hubungan adiksi game online dengan kualitas tidur pada anak di SMP Teratai Putih Global Bekasi tahun 2020.

\section{Rumusan Masalah}

Perkembangan teknologi dan akses internet memberikan banyak manfaat, tetapi kemajuan ini juga membawa efek samping buruk seperti munculnya fenomena game online sebagai hiburan global yang dapat berubah menjadi adiksi bagi penggemarnya. Berdasarkan penelitian sebelumnya adiksi 
game online dapat berpengaruh terhadap pola tidur, tapi hanya sedikit yang meneliti hubungan adiksi game online dengan kualitas tidur.

\section{METODE PENELITIAN}

\section{Desain Penelitian}

Penelitian ini merupakan jenis penelitian analitik observasional dengan desain Cross-sectional untuk mencari hubungan sebab akibat variabel independen dengan variabel dependen melalui pengukuran yang dilakukan satu kali dan dalam suatu waktu.

\section{Populasi dan Sampel}

Populasi pada penelian ini adalah seluruh siswa/i Sekolah Menengah Pertama (SMP) Teratai Putih Global Bekasi berjumlah 434 siswa. Sampel pada penelian ini adalah seluruh siswa/i Sekolah Menengah Pertama (SMP) Teratai Putih Global yang memenuhi kriteria inklusi dan eksklusi. Kriteria inklusi pada penelitian ini adalah siswa/i Sekolah Menengah Pertama (SMP) Teratai Putih Global Bekasi, remaja berusia di antara 10-18 tahun, bersedia menjadi responden dengan menandatangani lembar persetujuan. Untuk kriteria eksklusi pada penelitian ini adalah siswa/i yang mengonsumsi obat-obatan yang dapat menyebabkan mengantuk atau sulit tidur seperti antihistamine, beta blocker, alpha blocker, and antidepressan, siswa/i yang mengonsumsi alkohol dan merokok, siswa/i yang terbiasa minum kopi, siswa/i yang tidak mempunyai gadget seperti smartphone atau komputer, dan kuesioner yang diisi tidak lengkap.

\section{Pengambilan Sampel}

Teknik pengambilan sampel yang digunakan dalam penelitian ini adalah random sampling yaitu stratified random sampling. Stratified random sampling dilakukan dengan populasi dibagi menjadi dua segmen atau lebih yang mutually exclusive yang disebut strata, berdasarkan kategori dari satu atau lebih variabel yang relevan, baru kemudian dilakukan simple random sampling. Besar sampel ditentukan dengan menggunakan rumus uji beda proporsi. Berdasarkan rumus yang digunakan dalam penelitian ini, didapatkan jumlah sampel sebanyak 23 responden dan dikalikan dua menjadi 46. Kemudian responden akan ditambahkan 10\% dari besar sampel dengan maksud untuk mengatasi responden yang drop out sehingga jumlah responden pada penelitian ini adalah sebesar 51 responden.

\section{Pengumpulan Data}

Sumber data yang digunakan adalah data primer. Data primer diperoleh melalui kuisioner, yaitu membagikan daftar pertanyaan untuk dijawab oleh responden. Kuesioner yang digunakan adalah Indonesian Online Game Addiction Questionaire untuk menilai tingkat adiksi game online dan kuesioner kualitas tidur Pitsburgh Sleep Quality Index (PSQI).

\section{Prosedur Penelitian}

Pemilihan responden dibagi rata melalui stratified random sampling, kemudian diberikan kuesioner kriteria responden, responden yang memenuhi kriteria inklusi dan eksklusi mengisi kuesioner PSQI dan Indonesian Online Game Addiction Questionnaire (Alim, 2015; Jap et. al., 2013). Akumulasi penilaian dilakukan pada masing-masing kuesioner untuk mengelompokkan responden yang memiliki adiksi game online, adiksi game online ringan, tidak adiksi dan 
responden yang memiliki kualitas tidur baik atau buruk. Hasil pengukuran tersebut dicatat kemudian dianalisis.

\section{Analisa Data}

Hasil analisis data meliputi analisis univariat dan bivariat. Analisis univariat pada penelitian ini dilakukan pada masing-masing variabel yang diteliti yaitu variabel dependen kualitas tidur dan variabel independen adiksi game online. Sedangkan untuk analisis bivariat pada penelitian ini dilakukan untuk mengetahui hubungan adiksi game online dengan kualitas tidur pada siswa/i Sekolah Menengah Pertama (SMP) Teratai Putih Global Bekasi tahun 2020. Data hasil kuesioner Indonesian Online Game Addiction Questionnaire untuk kategori adiksi game online dan adiksi game online ringan dilakukan penggabungan sel dengan nama adiksi game online sehingga tabel berbentuk $2 \times 2$. Seluruh variabel bersifat kategorik sehingga dilakukan uji chi-square. Data penelitian telah memenuhi syarat uji Chi-square, yaitu sel yang mempunyai nilai expected kurang dari 5 maksimal berjumlah 20\% (Dahlan, 2014).

\section{HASIL DAN PEMBAHASAN}

Karakteristik responden penelitian meliputi kelas, usia, jenis kelamin, adiksi game online, dan kualitas tidur. Jumlah responden pada penelitian ini adalah 51, dari total tersebut didapatkan hasil kelas 8 dengan jumlah responden terbanyak sejumlah 19 siswa, kemudian dari rentang usia 12-15 tahun didapatkan mayoritas responden berumur 13 tahun, dan mayoritas responden berjenis kelamin perempuan.

Tabel 1. Distribusi Frekuensi Berdasarkan Adiksi Game Online

\begin{tabular}{lcc}
\multicolumn{1}{c}{$\begin{array}{c}\text { Adiksi Game } \\
\text { Online }\end{array}$} & N & \% \\
\hline $\begin{array}{l}\text { Adiksi Game } \\
\text { Online }\end{array}$ & 4 & 7,8 \\
\hline $\begin{array}{l}\text { Adiksi Game } \\
\text { Online Ringan }\end{array}$ & 29 & 56,9 \\
\hline Tidak Adiksi & 18 & 35,3 \\
\hline Total & 51 & 100 \\
\hline
\end{tabular}

Siswa yang mengalami adiksi game online didapatkan lebih banyak dibandingkan dengan yang tidak pada SMP Teratai Putih Global Bekasi seperti yang tertera pada tabel 1. Siswa yang mengalami adiksi game online berjumlah 33 responden $(64,7 \%)$, sedangkan yang tidak mengalami adiksi berjumlah 18 responden $(35,3 \%)$, hal ini sejalan dengan penelitian sebelumnya yang dilakukan oleh Azizah di SMK Dwija Bhakti 2 Jombang pada tahun 2018, yang menyatakan bahwa sebanyak 48 responden $(76,1 \%)$ memiliki kebiasaan bermain game online. Hal serupa juga ditemukan pada penelitian yang dilakukan oleh Nurdilla et. al. pada tahun 2018, dalam penelitiannya didapatkan sebanyak 44 responden $(62,9 \%)$ mengalami kecanduan bermain game online. Fenomena ini dapat terjadi dikarenakan perkembangan teknologi yang semakin maju, akses internet menjadi mudah untuk dijangkau oleh banyak kalangan. Pada survey yang dilaksanakan oleh We Are Social pada tahun 2019, terdapat 4,388 juta pengguna internet di seluruh dunia dengan penetrasi sebesar 57\%, dan sebanyak $30 \%$ dari pengguna internet tersebut menggunakannya untuk bermain game secara online. 
Tabel 2. Distribusi Frekuensi Berdasarkan Kualitas Tidur

\begin{tabular}{llc}
\hline \multicolumn{1}{c}{ Kualitas Tidur } & $\mathbf{N}$ & $\boldsymbol{\%}$ \\
\hline Buruk & 27 & 52,9 \\
\hline Baik & 24 & 47,1 \\
\hline Total & 51 & 100 \\
\hline
\end{tabular}

Berdasarkan tabel 2, kualitas tidur siswa SMP Teratai Putih Global Bekasi yang paling banyak didapatkan adalah kualitas tidur yang buruk, dengan jumlah responden sebanyak 27 responden (52,9\%). Hasil ini sejalan dengan penelitian sebelumnya yang dilakukan oleh Azizah di SMK Dwija Bhakti 2 Jombang pada tahun 2018 yang menyatakan bahwa sebanyak 70 responden (76,1 $\%)$ memiliki kualitas tidur buruk. Penelitian lain yang memiliki hasil serupa adalah penelitian yang dilakukan oleh Saputra di warung internet wilayah Kebumen pada tahun 2017, dimana sebagian besar respondennya memiliki kualitas tidur buruk $(55,6 \%)$.

Kualitas tidur yang buruk juga dapat dijadikan salah satu contoh dampak dari perkembangan teknologi seperti terdapatnya smartphone dan internet. Sebuah jurnal yang dibuat oleh Lin et. al. pada tahun 2019 menyatakan bahwa penggunaan smartphone sebelum tidur menjadi kebiasaan para remaja yang dapat memperlama latensi tidur dan menurunkan durasi tidur. Akses internet yang mudah melalui perangkat elektronik yang dimiliki menyebabkan peningkatan durasi penggunaan internet, seperti dapat menikmati berbagai aktivitas sosial yang menyenangkan, seperti bermain game, menonton film, dan menggunakan sosial media. Hal ini dapat menjelaskan mengapa terdapat lebih banyak responden dengan kualitas tidur buruk.

Tabel 3. Hubungan Adiksi Game Online dengan Kualitas Tidur

\begin{tabular}{|c|c|c|c|c|c|c|c|}
\hline \multirow{3}{*}{$\begin{array}{l}\text { Adiksi Game } \\
\text { Online }\end{array}$} & \multicolumn{6}{|c|}{ Kualitas Tidur } & \multirow{3}{*}{ Nilai $\mathbf{p}$} \\
\hline & \multicolumn{2}{|c|}{ Buruk } & \multicolumn{2}{|c|}{ Baik } & \multicolumn{2}{|c|}{ Total } & \\
\hline & $\mathbf{N}$ & $\%$ & $\mathbf{N}$ & $\%$ & $\mathbf{N}$ & $\%$ & \\
\hline Buruk & 23 & 45,1 & 10 & 19,6 & 33 & 64,7 & \multirow{2}{*}{0,001} \\
\hline Baik & 4 & 7,8 & 14 & 27,5 & 18 & 35,3 & \\
\hline Total & 27 & 52,9 & 24 & 47,1 & 51 & 100 & \\
\hline
\end{tabular}

Berdasarkan hasil analisis bivariat menggunakan uji Chi Square, diperoleh nilai p 0,001 $(\mathrm{p}<0,05)$ yang berarti bahwa terdapat hubungan yang signifikan antara adiksi game online dengan kualitas tidur seperti yang tertera pada tabel 3. Hasil analisis bivariat tersebut sesuai dengan teori yang dijabarkan oleh Sosso et. al. pada tahun 2018, yaitu dengan memperkirakan dampak dari cahaya, lingkungan yang membuat stress, stimulasi visual dan bermain game yang berlebihan, kemungkinan memiliki pengaruh pada kualitas tidur dan psikopatologi seseorang. Sosso et. al. juga menyatakan bahwa paparan dari cahaya, seperti dari perangkat elektronik, dapat mengganggu ritme sirkardian, siklus melatonin, dan plastisitas serebral. Cahaya warna biru (blue light) yang biasa terdapat pada alat elektronik yang kita gunakan seperti smartphone dan TV, menyebabkan behavioural arousal, meningkatkan kortikosteron dan memperlambat onset tidur. Tetapi, hingga saat ini belum terdapat literatur sains yang membuktikan hipotesa tersebut secara pasti. 
Beberapa penelitian yang mendahului memberikan hasil penelitian yang selaras dengan hasil analisis bivariat dari penelitian ini. Salah satunya adalah penelitian yang dilakukan oleh Nurdilla pada tahun 2018 dimana disimpulkan bahwa ada hubungan antara kecanduan bermain game online dengan kualitas tidur pada remaja. Pada penelitian yang dilakukan Astuti yang dilakukan di SMP Negeri 24 Samarinda pada tahun 2018 juga memberikan hasil serupa dengan terdapatnya hubungan yang bermakna antara kecanduan bermain game online dengan kualitas tidur. Hasil tersebut juga selaras dengan penelitian yang dilakukan oleh Azizah pada tahun 2018 yang berlokasi di SMK Bhakti 2 Jombang.

Hasil tersebut juga dapat didukung penelitian yang dilakukan oleh Peracchia et. al. pada tahun 2018. Penelitian tersebut menjabarkan hasil analisis dari efek bermain video game berupa reduksi dari waktu tidur total atau Total Sleep Time (TST), peningkatan Sleep Onset Latency (SOL), modifikasi tidur REM dan Slow Wave Sleep (SWS), serta peningkatan rasa mengantuk dan letih. Sehingga dapat disimpulkan bahwa bermain game dalam durasi yang lama, terutama pada malam hari, adalah faktor yang signifikan dalam menyebabkan gangguan tidur disertai dengan kemungkinan efek samping terhadap kemampuan kognitif.

Tidak semua penelitian terdahulu memiliki hasil yang serupa, terdapat juga penelitian dengan hasil yang terlihat bertolak belakang dengan teori yang digunakan oleh peneliti. Penelitian yang dilakukan oleh Peracchia et. al. pada tahun 2017 meneliti apakah bermain video game dapat diasosiasikan dengan kualitas tidur yang lebih baik. Kegiatan bermain video game dalam penelitian ini diasosiasikan dengan kegiatan dan aktivitas lain yang intens seperti olahraga. Penelitian ini membagi respondennya menjadi dua kelompok, yaitu hard gamers (HG) yang bermain hampir setiap hari selama 4-6 jam dan casual gamers (CG) yang hanya bermain sewaktuwaktu dengan waktu kurang dari 1 jam. Hasil yang didapatkan menunjukkan bahwa kualitas tidur secara keseluruhan lebih baik pada kelompok hard gamers (HG), hal ini bisa dikarenakan aktivitas fisiologis yang lebih banyak pada kelompok hard gamers.

\section{KESIMPULAN DAN SARAN}

\section{Kesimpulan}

Berdasarkan hasil dari analisis dan pembahasan yang telah dilakukan pada penelitian ini, dapat diambil kesimpulan bahwa terdapat hubungan yang signifikan antara adiksi game online dengan kualitas tidur pada siswa SMP Teratai Putih Global Bekasi. Hubungan antara adiksi game online dengan kualitas tidur telah dibuktikan dalam beberapa penelitian. Penelitian-penelitian tersebut menyatakan bahwa adiksi game online memilki pengaruh yang buruk terhadap kualitas tidur seseorang. Tetapi, ada penelitian lain yang menyatakan bahwa bermain game online memiliki dampak yang baik dan bertolak belakang dengan penelitian lainnya. Penelitian seputar video game dan kualitas tidur masih sangat sedikit, sehingga riset lebih lanjut dan penilaian kualitas tidur yang objektif diperlukan untuk menghindari data yang tidak akurat.

\section{Ucapan Terima Kasih (Acknowledgement)}

Penulis mengucapkan terimakasih kepada SMP Teratai Putih Global Bekasi atas ketersediaannya untuk menjadi tempat penelitian. 


\section{REFERENSI}

Alim, IZ. (2015). Uji Validitas dan Reabilitas Instrumen Pittsburgh Sleep Quality Index Versi Bahasa Indonesia. Tesis Pendidikan Dokter Spesialis Program Studi Ilmu Kesehatan Jiwa, Universitas Indonesia.

American Psychiatric Association (APA). (2013). Diagnostic and statistical manual of mental disorders: DSM-5 ${ }^{\mathrm{TM}}$, 5th ed.

Astuti, S. (2018). Hubungan Kecanduan Bermain Games Online dengan Kualitas Tidur pada Siswa/siswi di SMP Negeri 24 Samarinda. Program Studi Ilmu Keperawatan, Universitas Muhammadiyah Kalimantan Timur.

Azizah, L. (2018). Hubungan Kebiasaan Bermain Games Online dengan Kualitas Tidur Remaja pada Kelas X di SMK Dwija Bhakti 2 Jombang. Skripsi Program Studi Ilmu Keperawatan Sekolah Tinggi Ilmu Kesehatan Insan Cendekia Medika Jombang.

Chiu, S. Lee, J. Huang, D. (2004). Video Game Addiction in Children and Teenagers in Taiwan. Cyberpsychology \& Behavior, Vol.7, No.5, hlm.571-581.

Dahlan, MS. (2014). Statistik untuk kedokteran dan kesehatan, Edisi 6. Salemba Medika, Jakarta.

Griffiths, MD. (2010). The role of context in online gaming excess and addiction: Some case study evidence. International Journal of Mental Health and Addiction, vol.8, no.1, hlm.119-125.

Hale, L. \& Guan, S. (2015). Screen time and sleep among school-aged children and adolescents: A systematic literature review. Sleep Medicine Reviews. W.B. Saunders Ltd. Vol. 21, p. 5058.

Higuchi, S. Motohashi, Y. Liu, Y. Maeda, A. (2005). Effects of playing a computer game using a bright display on presleep physiological variables, sleep latency, slow wave sleep and REM sleep. J Sleep Res. 2005;14(3):267-273.

Jap, T. Tiatri, S. Jaya, ES. Suteja, MS. (2013). The Development of Indonesian Online Game Addiction Questionnaire. PLoS One. 2013;8(4):4-8.

Lin, PH. Lee, YC. Chen, KL. Hsieh, PL. Yang, SY. Lin, YL. (2019). The relationship between sleep quality and internet addiction among female college students. Front Neurosci. 2019;13(JUN):1-9.

Nurdilla, N. Arneliwati, Elita, V. (2018). Hubungan Kecanduan Bermain Game Online dengan Kualitas Tidur Remaja. JOM FKp. 2018;5(2):120-6.

Peracchia, S. Triberti, S. Curcio, G. (2017). Longer the game, better the sleep: Intense video game playing is associated to better sleep quality and better daytime functioning. Annu Rev CyberTherapy Telemed. 2017;15(December):204-6.

Peracchia, S. \& Curcio, G. (2018). Exposure to video games: Effects on sleep and on post-sleep cognitive abilities. A systematic review of experimental evidences. Sleep Science. Brazilian Association of Sleep and Latin American Federation of Sleep Societies; 2018, Vol. 11, p. 302-14.

Pilorz, V. Tam, SKE. Hughes, S. Pothecary, CA. Jagannath, A. Hankins, MW. et. al. (2016). Melanopsin Regulates Both Sleep-Promoting and Arousal-Promoting Responses to Light. PLoS Biol. 2016;14(6):1-25.

Saputra, RA. (2017). Hubungan Kecanduan Bermain Game Online Dengan Kualitas Tidur Pada Remaja Usia 13-16 Tahun Di Warnet Wilayah Kebumen. Sekolah Tinggi Ilmu Kesehatan Muhammadiyah Gombong. Sekolah Tinggi Ilmu Kesehatan Muhammadiyah Gombong.

Sosso, FAE. \& Kuss, DJ. (2018). Insomnia and problematic gaming: A study in 9 low-and middleincome countries. Biorxiv. 
Sussman, CJ. Harper, JM. Stahl, JL. Weigle, P. (2018). Internet and Video Game Addictions: Diagnosis, Epidemiology, and Neurobiology. Child and Adolescent Psychiatric Clinics of North America. W.B. Saunders; 2018, Vol. 27, p. 307-26.

We Are Social. (2019). Digital 2019: Global Internet Use Accelerates - We Are Social.

Weinstein, AM. (2010). Computer and video game addiction-A comparison between game users and non-game users. Am J Drug Alcohol Abuse. 2010;36(5):268-76.

World Health Organization (WHO). (2019). International Classification of Diseases 11th Revision (ICD-11). World Health Organization (WHO). 